\title{
Reconsidering Early Modern Women’s Reading, or, How Margaret Hoby Read Her de Mornay
}

\author{
Julie Crawford
}

\begin{abstract}
This article re-examines the life and reading of Lady Margaret Hoby, a Yorkshire gentlewoman best known for her diary, which often records her practice of reading devotional texts. Reading the diary alongside Hoby's annotations of Philippe de Mornay's controversial text on the Eucharist, Julie Crawford argues that Hoby's practices of reading, writing, and talking about religion were more than simply inward-looking acts of self-examination, but functioned as a way of asserting her influence and furthering reform in a notoriously recusant region, and of fostering a network of like-minded activists both in the country and in London. The case of Hoby challenges our view of women's diaristic writing, and pietistic reading, as private and internal, showing how in this case these practices functioned as social and political activism. KEYWORDs: women's religious and political influence; diary; marginalia; gendering of private and public; Puritanism
\end{abstract}

\begin{abstract}
- THE SUBTITLE OF THIS ESSAY echoes that of an influential essay by Lisa Jardine and Anthony Grafton, "How Gabriel Harvey Read His Livy." I omitted the main title, "Studied for Action,'” not only to avoid charges of a complete failure of imagination, but also to make the point, by omission, that one does not normally think of Margaret Hoby, or indeed of any woman reader, as a woman of action. When she is thought of, Hoby is remembered rather as a typical Elizabethan country gentlewoman (of Hackness, Yorkshire) of church-Puritan leanings who authored a somewhat famous diary (kept 1599-1605) recording her domestic and community life, her personal piety, and her extensive reading. ${ }^{1}$ Nor, for that matter, does one think of the work

1. The diary, MS Egerton 2614, currently at the British Library, covers the period between 9 August 1599 and 21 July 1605. In addition to the two scholarly editions, Diary of Lady Margaret Hoby, 1599-1605, ed. Dorothy M. Meads (Boston, 1930), and The Private Life of an Elizabethan Lady: The Diary of Lady Margaret Hoby 1599-1605, ed. Joanna Moody (Stroud, U.K., 1998), a facsimile of the manuscript is available through the Perdita Project, http://www.perditamanuscripts.amdigital.co.uk. All subsequent references to the diary will be to the Meads edition.
\end{abstract}

Pp. 193-223. (C)2010 by Henry E. Huntington Library and Art Gallery. ISSN 0018-7895 | E-ISSN 1544-399x. All rights reserved. For permission to photocopy or reproduce article content, consult the University of California Press Rights and Permissions website, http://www.ucpressjournals.com/reprintInfo.asp. DOI: 10.1525/hlq.2010.73.2.193.

HUNTINGTON LIBRARY QUARTERLY | VOL. 73, NO. 2 
of the Huguenot Philippe du Plessis de Mornay as action reading. ${ }^{2}$ What I want to argue here is that we are wrong on both accounts. Indeed, I want to argue that Hoby's reading, rather than simply being part of a typical Puritan program of self-examination, was in fact deeply imbricated with her religio-political activism in Yorkshire, a region notorious for recusancy, busily and ineffectively policed by her litigious husband, and embroiled in power struggles that played out both internally and between the country gentry and the London court during this fraught period of religious and political transition. Her reading corresponded with specific religious and regional concerns and debates in which she was actively concerned; indeed many of the books she read were by local authors. While Hoby certainly had devotional purposes in mind when she chose texts as well as the people with whom she read them, she also chose both texts and readers with an eye toward religious and political influence.

While they were not exactly "scholarly transactions" in the sense that Jardine and William Sherman have outlined (Hoby was not hired by anyone to read to or for them, nor, as far as we know, did she hire a secretary to read to her), Hoby's dialogic and communal reading practices were nonetheless "goal-directed" in the sense that they sought real-world effects. ${ }^{3}$ And while it is possible to see her reading habits as "familial" or "sociable" practices characteristic of godly culture, neither term adequately captures the scope of her practice, a region-wide "sociability" that also engaged with the metropole, nor its frequently interpellative and occasionally interconfessional nature. 4 Deeply and minutely engaged with reformist Protestant texts and activism, Margaret Hoby's reading practices were regional transactions in which her often very public reading intersected with other forms of sociability to influence local sentiment, belief, and religious and political action. In fact, I would argue that, in addition to her insistent co-reading and conversations with the members of her household, neighbors, local clergy, and visitors, Hoby's frequent forays into her "feeldes," "pastur," and the "dalls" (the regions comprising her property) — what she in her diary calls "reed[ing] abroad"-made her a kind of perambulatory intellectual and political presence, at once catechistical, conversational, and proprietary. 5 Her reading, in other words, was a

2. This despite the fact that he is credited with co-authoring one of the most famous Renaissance treatises on antimonarchical rebellion. On the Vindiciae contra tyrannos, often attributed to Hubert Languet and du Plessis de Mornay, see Constitutionalism and Resistance in the Sixteenth Century: Three Treatises by Hotman, Beza, \& Mornay, trans. and ed. Julian H. Franklin (New York, 1969).

3. On the term, "goal-directed," see Lisa Jardine and Anthony Grafton, “'Studied for Action': How Gabriel Harvey Read His Livy," Past and Present 129 (1990): 30-78 at 31. See also Lisa Jardine and William Sherman, "Pragmatic Readers: Knowledge Transactions and Scholarly Services in Late Elizabethan England," Religion, Culture and Society in Early Modern Britain: Essays in Honour of Patrick Collinson, ed. Anthony Fletcher and Peter Roberts (Cambridge, 1994), 102-24.

4. In "Reading, the Godly and Self-writing in England, Circa 1580-1720," Journal of British Studies 46 (2007): 769-825, Andrew Cambers locates diaries and autobiographies "as much in the public context of the religious community as in the realm of the private self" (796) and focuses on such writings as "familial" and "sociable" practices.

5. A diary entry on one of these forays reads: "after privat prairs and taking order for the house, I went to the dalls: and, after a Lecture there, I dined wt diverse others wiffes" (190; see also 184, 185). Lady Hoby's manor of Hackness, the rectory, and her surrounding lands in Harwood Dale, Silpho, Suffield, 
means of actively asserting herself in the region she sought to both save and control. This essay thus seeks not only to take women's reading out of the closet and into the political arena but also to examine the influence it had in a specific, politically volatile region at a key moment in English history.

“ "TT]he most dangerous parts of Yorkshire for hollow hearts, for popery" It is frequently asserted that Protestantism necessarily entailed a turn to the private and inward, and Puritanism to minute self-examination and obsession with providence and personal salvation. Yet for many, including Margaret Hoby, Puritanism prompted a turn outward. Hoby's public included not only her own household, but also the (often Catholic-leaning) people of the North Riding of Yorkshire. On August 27, 1599, during the same month in which Margaret Hoby began writing in her diary, John Whitgift, archbishop of Canterbury, wrote to Matthew Hutton, archbishop of York, about the "informations given that recusants are of late increased in that province, and that you are to[o] milde with them. Some of your ministers doe also affirme the same to be trewe. My advice therefore ys, that your Lordship make a true declaration in writing how that province standeth in that pynte and this tyme." 6 Yorkshire was undoubtedly full of recusants. Whitby, the hundred in which Hackness was situated, had thirty-two recusants and four non-communicants, according to the Presentment Book for 1595-96,7 and by the end of 1595 thirty priests had been executed in the north (mostly in York) and eight laypeople had been convicted of harboring priests. ${ }^{8}$ Hackness, however, was also the new home of Sir Thomas Posthumous Hoby, a man eager to "winn ... commendation" to himself by highlighting the evils of recusancy in the area. 9

Sir Thomas Hoby had in fact been planted in the region by means of his 1596 marriage to Margaret (née Dakins) Devereux Sidney, who owned property there. The alliance was engineered by powerful court figures, the Cecils and the Earl and Countess of Huntingdon; Huntingdon encouraged Margaret to accept Hoby not for any merits of his own, which were reportedly few, but for "Gods cawse." ${ }^{10}$ He was, in short,

Hingles, and Everley, were worth $£ 1,500$ a year at her death (see Dorothy M. Meads, "Introduction," Diary, 1-61 at 43). I discuss "reed[ing] abroad" further below.

6. Matthew Hutton, The Correspondence of Dr. Matthew Hutton, Archbishop of York, Surtees Society 17 (London, 1843), 147. Subsequent references to Hutton's correspondence will be cited in the text.

7. J. S. Purvis, Tudor Parish Documents of the Diocese of York (Cambridge, 1948), 48. In these records Yorkshire Catholics show a wide range of religio-intellectual practices; they also show resistance to Protestant religious and studious practices (see 48, 133). The standard account of Catholicism in the region is Hugh Aveling's Northern Catholics: The Catholic Recusants of the North Riding of Yorkshire, 1558-1790 (London, 1966).

8. Claire Cross, The Puritan Earl: The Life of Henry Hastings Third Earl of Huntingdon, 1536-1595 (London, 1966), 243.

9. In his letter to Hutton about recusancy, Whitgift went on to suggest that recusant-hunting could be a tool of political ambition: "for it may be some men's pollicie to make things worse then they are, to effect there desyers and to winn the commendation to themselfes" (Hutton, Correspondence, 147).

10. Meads, "Introduction," 26, 30. As Meads notes, even Hoby's mother had her doubts about his character: "the unnatural hard nature and insolency of this boy hath exceded his brothers ... What his owne infirmityes and insufficiency by want of stature, learning, and otherwise be, I know" (24). 
meant to serve as a counterweight to the recusant and Catholic-sympathizing gentry in northeastern Yorkshire, particularly the powerful Eure and Cholmley families. ${ }^{11}$ In 1597, Archbishop Hutton considered Hoby to be "a gentleman of very great hope," and others saw him as an able justice of the peace, known for recording warrants "in a booke" he kept with him at all times. ${ }^{12}$ There was also, however, some local resentment of Hoby as an interfering outsider; one local man called him "the busiest saucy little Jack in all the country [who] would have an oar in anybody's boat."13 By 1601 he was, among other things, a commissioner of the peace for the North and East ridings of Yorkshire, had been recommended for election to the Council of the North, and was listed as a high commissioner for the Province of York. He was also, moreover, a renowned recusant hunter. When an attack was to be made on a house suspected of harboring Papists in April 1599, the man in charge of the raid declared to Sir Robert Cecil that with Sir Thomas away in London, he knew "of no faithfull assistance in the country." 14 In her diary Margaret Hoby reports Sir Thomas receiving "Leters, touchinge Recusants, from the Counsill [of the North]," as well as going on a number of different occasions to nearby towns "to take order for recusants" or "to sitt upon a Comition for recusantes" (218, 219, 220). Indeed, Sir Thomas Hoby's interactions with his recusant neighbors were conducted primarily in two ways: the exacting local administration of justice and litigation.

Margaret Hoby certainly participated in many of her husband's tasks as a godly householder in the recusant north, and frequently recorded these activities in her diary. One day in August 1599, for example, Hoby reports that she "walked with Mr Hoby about the toune to spye out the best places where Cotiges might be builded," and, later in the evening, "helped Mr Hoby to Looke over some papers" (65). She notes that she spoke "privately, with Mr. Hoby, of matters concerninge Conscience and our estates," and, on another occasion, helped "to read of the book for the placing of the people in the church to Mr Hoby" $(66,69)$. She makes a record on September 4, 1601, of talking with Sir Thomas "of some Complaintes made to him," and then "Cop[ying] out a letter which [he] had wretten to the Busshopp of Limbricke [Limerick]" (185), John Thornborough. On August 23, 1601, she writes that she was going "about to gett some thinges readie against my Lord presedent Cominge" (184), referring to a visit from Thomas Cecil, Lord Burghley, the newly appointed president of the Council of the

11. On these local power dynamics, see G. C. F. Forster, "Faction and County Government in Early Stuart Yorkshire," Northern History 11 (1976): 70-86 at 74. See also G. C. F. Forster, “The North Riding Justices and Their Sessions, 1603-1635," Northern History 10 (1975): 102-25.

12. Sir William Brereton saw him as "the most understanding, able, and industrious justice of peace in this kingdome. Noe warrant graunted out butt he takes notice thereof in a booke: and att sessions an account demaunded of all those warrants sent out"; "Journal of Sir William Brereton," North Country Diaries (Second Series), ed. J. C. Hodsgon, Surtees Society 124 (Durham, U.K., 1915), quoted in Meads, "Introduction," 34-35.

13. Quoted in Forster, "Faction," 74.

14. Calendar of State Papers Domestic: Elizabeth, 1598-1601, vol. 270, no. 99; cited in Meads, "Introduction," 35 (see also 35 n. 112). 
North. She also took care to record her role in the sessions of the Hackness Manor Courts. As she writes on August 4, "this day I was busie in the house, havinge manie strangers, because of the Courte that was kept after Mr Hoby and my self, by godes goodness, had gotten thestate of Hackness" (181). ${ }^{15}$ Indeed, the gratitude Hoby expresses for "godes goodness" refers to his providential assurance of their victory in a battle with their recusant neighbors over the right to hold such a court.

Yet while Sir Thomas and Margaret Hoby frequently shared household responsibilities, both Margaret and many others considered the Hackness property to be Margaret's rather than her husband's; her kinsmen had, after all, purchased it for her and her previous husband Walter Devereaux. ${ }^{16}$ Indeed, in her diary she often differentiates between "her" workers and those of her husband when discussing Hackness business, and makes occasional references to her differences with her husband. ${ }^{17}$ (The two also engaged in a protracted battle over whose kin would inherit the property after Margaret's death. ${ }^{18}$ Moreover, as a notorious local incident indicates, Margaret Hoby's interactions with her neighbors, especially those who were recusant, were notably different from her husband's. On August 26/7, 1600, a visit by the heads of the Eure and Cholmley families and their large hunting party to Hackness manor went terribly awry. ${ }^{19}$ There is some evidence that the "visit" was motivated by hostility against Sir Thomas. As he wrote to his cousin Sir Robert Cecil following the incident, problems had been brewing between the families before the hunting party's visit: "there hasbeen some dryness in the Lord Ewre (whose tenants are my next neighbours) almost ever since I was employed as a commissioner in these parts." ${ }^{20}$ A hostile witness

15. Meads explains that "this was a court of special sessions held for the inhabitants of the manor of Hackness by the owner of the manor, and attended by JPs from the immediate district." Meads also recounts Hoby's assertion of his right of jurisdiction over his manor against the Cholmley family of Whitby; Diary, 270-71 n. 487.

16. See, for example, the memoirs of their recusant neighbor, Richard Cholmley, who identifies Sir Thomas as "a troublesome, vexatious neighbour ... who having married a widow, the inheritor of all Hackness lordship, having a full purse, no children (and as it was thought not able to get one), delighted to spend all his money and time in suits"; The Memoirs of Sir Hugh Cholmley (n.p., 1870), 14, quoted in Meads, "Introduction," 33 and 237 n. 106.

17. For examples of Hoby's differentiation between their workers, which Meads also notes, see 123, 265 n. 348,81 . For her differences with her husband and the suggestion that he distracts her from her spiritual practice, see 64-65, 69.

18. See Meads, "Introduction," 43-45.

19. On the visit and its litigated aftermath, see Royal Commission on Historical Manuscripts, Calendar of the Manuscripts of the Most Honourable, the Marquess of Salisbury Preserved at Hatfield House, Hertfordshire, Part X (London, 1904), 302-4; Aveling, Northern Catholics, 118-20; Felicity Heal, "Reputation and Honour in Court and Country: Lady Elizabeth Russell and Sir Thomas Hoby," Transactions of the Royal Historical Society 6, no. 6 (1996): 161-78; Forster, "Faction"; Meads, "Introduction," 40-43, and Diary, 269-72 n. 368. Joanna Moody also provides some extracts from the correspondence and evidence relating to the case in appendix 2 of her edition of the diary. Sir Hoby charged the hunting party with "riotous assault" before the Council of the North, and, eventually, the Star Chamber (Meads, Diary, 270 n. 368).

20. Quoted in Meads, Diary, 270 n. 368. 
claimed that, well before the incident, Sir Christopher Hillyard had said "there was a sorte of younge fellows in Yorkshire wolled plaie him [Hoby] a tricke were it were longe and when it were done he should not mende himselfe" and that another visitor had proposed to pull down the local church because he knew "the Lord of the Mannor [Hoby] was tyed to buyld yt agayne." ${ }^{21}$ Sir Thomas Hoby, in other words, was the target of general local spite.

During their visit, the hunting group reportedly interrupted prayers with noises variously described as "very lowde straunge and wylde," "a catch or a song of prynce Arthurs," and a "black sanctus," or burlesque hymn. ${ }^{22}$ While aggressive festivity characterized the visit in general - the party also played cards and drank to excess - the singing of the "black sanctus" was clearly a direct assault on and mockery of the Hoby family's godly practices. (Hoby frequently refers to household psalm singing in her diary.) The formal depositions of the Eures and their adherents, however, were, as Felicity Heal puts it, "at pains to stress that no insult was intended to Lady Margaret"; indeed, "some comments suggest that she was respected by her neighbours." Heal claims that the Hobys "made no secret of their alienation from the values of local society," but as my argument, and the account itself, suggest, Margaret Hoby behaved very differently from her husband, evincing not "alienation" but consistent and varied forms of sociability. 23

In his deposition, William Eure reports that while Thomas Hoby's behavior was "not answerable to our northern entertainments," Margaret Hoby was less contrary and did, in fact, "shew some dislike of her husband's strange behavior." 24 Their differing reputations were, at least in some ways, related to Margaret's habitual practices of reading and conversation. While Thomas Hoby singled out both the Eure and Cholmley families for persecution, writing to Cecil in February 1601 that Richard Cholmley's living "lieth in the most dangerous parts of Yorkshire for hollow hearts, for popery," 25 and accusing him of a role in the Essex conspiracy, Margaret Hoby had numerous sociable interactions with both families. On several occasions she mentions writing "to my Lady Ewre" (69) and, on others, visiting her in person. On September 18, 1599, for example, Hoby "took my Cocth, and wente to malton to salute my Lady Ewre, with whom I staied about :2: houres" (73). The length of the visit suggests a more than superficial sociability. Indeed, Hoby also visited Lady Eure on May 30, 1600, less than two months before the hunting visit (123). While one might read these visits solely as female socializing and thus purportedly separate from the public and political affairs of men, it is telling that on April 29, 1600, a month before the above visit with Lady Eure, Lady Hoby also "kept Companie with Mr Cholmely tell allmost night" (117). Indeed, Hoby records at least two earlier visits with Richard Cholmley: on August 27, 1599, she

21. Heal, "Reputation and Honour," 170-71.

22. Ibid., 171.

23. Ibid., 173, 171, 163 .

24. Manuscripts of the ... Marquess of Salisbury, 302-4.

25. Meads, "Introduction," 34, see also 237-38 n. 109. 
records talking "a little with Mr Cholmley" during an evening when her husband is away in York (67), and on December 26, 1599, talking with Mr Cholmley "of diverse thinges" (92). While she gives no account of what "diverse thinges" they talked of during these visits, "talking," for Margaret Hoby, was almost always tied to religious, intellectual exchange.

Indeed, if Margaret Hoby's way of interacting with powerful local recusant families was different from her husband's, it was in keeping with her textually mediated engagement with the local problem of Catholicism in general. On May 16, 1600, for example, Hoby makes a record in her diary of hearing her minister "Mr. Rhodes read of the principles of poperie out of one of their owne bookes" (120), a practice in which they engage intently for a few days (see also the entry for May 19: "Hard Mr Rhodes read of a popeshe booke"). An officially illegal act in Elizabethan England, although one practiced by many theologically and politically active Protestants, Hoby's studious reading of a Catholic book suggests she meant to use it for "talking." ${ }^{6} 6$ The day after this reading of a "popeshe booke," Hoby records talking "with a good Christian touchinge sundrie infirmetes that our humaine nature is subject to" (121), a topic, as the term "good Christian" suggests, familiar across confessional lines. On February 24, 1599, moreover, Hoby records spending her evening in the following way: "saluted some strangers: after praied and then dined: after, I kept Companie tell they departed and, after, reed and talked with a yonge papest maide" (105).

Hoby's choice of a reading partner is illustrative. Not only were women largely responsible for keeping Catholicism alive in Protestant England, but there were far more recusant women in Yorkshire than men. ${ }^{27}$ These women, moreover, were famed for being particularly intellectually and theologically astute. In his record of spying

26. Many English Protestants believed Catholic books to be dangerous, at least for certain readers; see, for example, Hutton, Correspondence, 167. The York lawyer, MP, and member of the Council of the North, Sir Edward Stanhope (d. 1608) - who was close to Margaret Hoby-also read Catholic texts that it would be treasonable for anyone else to have, and may have shared them with her. See John Barnard and Maureen Bell, The Early Seventeenth Century York Book Trade and John Foster's Inventory of 1616 (Leeds, U.K., 1994), 30. For other Protestant women who read Catholic books, see David McKitterick, "Women and their Books in Seventeenth-Century England: The Case of Elizabeth Puckering," The Library, 7 th ser., 1 (December 200o): 359-80; Arnold Hunt, “The Books, Manuscripts, and Literary Patronage of Mrs. Anne Sadleir (1585-1670)," Early Modern Women's Manuscript Writing: Selected Papers from the Trinity/Trent Colloquium, ed. Victoria E. Burke and Jonathan Gibson (Aldershot, U.K., 2004), 205-36, 210, 215. In addition to providing ammunition for argument or proselytizing, reading Catholic books may well have been a family tradition for Hoby: amongst the books of Ripon Minster is a thirteenth-century manuscript summary of the Bible in Latin verse; in the margin of one page is written "Arthure Dakyns" (Meads, "Introduction," 47).

27. In many ways, women were responsible for keeping the Catholic faith alive during time of Protestant rule, particularly in Yorkshire. The 1604 recusant rolls for Yorkshire, to take one example, list almost 400 more women than men who were presented for recusancy. See Sarah L. Bastow, “'Worth Nothing, But Very Wilful': Catholic Recusant Women of Yorkshire, 1536-1642," Recusant History 25, no. 4 (2001): 591-603 at 597. For English recusant women generally, see Marie B. Rowlands, "Recusant Women, 1560-1640," Women in English Society, 1500-180o, ed. Mary Prior (London, 1985), 149-80. 
on and eventually executing a group of recusants, Sir Edward Stanhope, a senior member of the Council of the North, notes that the women were particularly "perilous," "not only for their recusancy, but for speaking boldly against the state, persuading others, and dealing abroad with women." ${ }^{28}$ Stanhope's claim that these highly effective disputants were particularly committed to "dealing abroad" with women, evokes the kind of mobile, evangelical mode of conversation and disputation that Hoby herself deployed. Indeed, it is telling that Stanhope himself was a frequent visitor to Hackness (74). ${ }^{29}$ As with her Eure and Cholmley visits, Hoby notes nothing of the content-or purpose—of her conversation with the "yonge papest maide," what text(s) they read, or what points of controversy or commonality they touched upon. Yet her reading and talking with a young Catholic woman stands in sharp relief to the bare note she makes the following month: "Mr Hoby that night went to search a house for papists" (March 24, 1599/1600; 110), an enterprise doubtlessly more violently persecutory than dialogically argumentative.

While she was certainly concerned with recusancy, Hoby's reading practices were not geared solely toward Catholics. "[A]fter the sarmone ended," on Sunday, October 7, 1599, for example, she "read a whill of the Bible" to Mrs. Ormston, one of the members of her household and certainly no recusant (76). Such intra-household and intra-confessional forms of reading and discussion were nonetheless clearly intended to influence her hearers in specific directions. On August 10, 1599, for example, she "went about the house, and instructed Tomson wiffe in som principles of relegion" (62). Nor did her readings and conversations always take place within the home or within the limited parameters of known or domestic relations. While Hoby regularly read with her husband, and "instructed som of [her] famelie" on August 30, 1599 (67), she was as often occupied reading books and discussing sermons with a wide range of communicants: her own "wemen" and "workwemen" (130, 81)—women who worked as servants, tenants, or workers in her fields, local "good wiffes" and "gentlewomen" (136, 131, 189), "neighbours" (190), members of the local clergy, and, frequently, "strangres as Came to [her]" (71).

28. Katharine M. Longley, "Blessed George Errington and Companions: Fresh Evidence." Recusant History 19 (1988): 39-46 at 43, 44. In 1609 Sir Edward Hoby, Margaret Hoby's brother-in-law (and a Puritan lobbyist himself) dedicated a polemical letter to a newly converted Jesuit "To All Romish Collapsed Ladies of Great Britanie," joking that the fastest way to get his castigatory missive to its addressee at St. Omer is "by your Ladiships meanes, as having weekely newes from the English house"; A Letter to Mr. T. H. Late Minister: now fugitiue: from Sir Edvvard Hoby Knight. In answere of his first Motiue (London, 1609), A2. Hoby's concern with the intellectual attentions and activities of women in this work acknowledges the central role that women played in religious controversy in postReformation England. See also his later pamphlet, A Curry-Combe for a Coxe-Combe (London, 1615), in which he contrasts Protestant and Catholic women's religious understanding.

29. The Stanhopes were also her cousins. On the powerful Edwardian Protestant circle, led by William Cecil, to which the Hobys were connected, see Pauline Croft, "Capital Life: Members of Parliament outside the House," in Politics, Religion and Popularity in Early Stuart Britain: Essays in Honour of Conrad Russell, ed. Thomas Cogswell, Richard Cust, and Peter Lake (Cambridge, 2002), $65-83$ at $71-72$. 
Hoby's most frequent reading, writing, and discussion partner was her personal chaplain, Richard Rhodes. In meetings recounted in her diary, she variously examines "that I had wreten with Mr Rhodes" (63); has "Mr Rhodes read a chapter" to her (64); talks "with Mr Rhodes of the lordes praier, and, after lector ... meditated a little of that I had hard" (64); talks "of good matters with Mr Rhodes and Mr Maude, a younge devine, a exceedinge good Christian" (89); and hears him read numerous books to her, including "Mr Cartwright and the Bushoppe of Canterberies booke" and "a booke against some newe spronge up heresies" $(99,98)$. Not only do the texts range between the central text of Presbyterian/Church of England controversy to the immediately topical, but, like her conversations, they are often records of discussion and debate. The verbs she uses to describe her scholarly interactions with Rhodes- "meditate," "examine," "talk," "hear," "write" - suggest the range and variety of their intellectual activity as well as the varied nature of her own role in this activity. Rather than being a passive recipient of ideas, Hoby actively pursues knowledge. In addition to frequently recording the conversations and discussions she has with Rhodes about a wide range of subjects, she notes the occasions on which she "has" Rhodes read her a given text, suggesting her own agency. For example, on August 16, 1599, she "hadd Mr Rhodes read a chapter" to her before she went to bed (64).

Moreover, Hoby's varied intellectual and dialogic encounters with Rhodes are by no means solely or even primarily concerned with her personal salvation or education. One night in August 1599, to take an example, "Mr Rhodes and my selfe had som speech with the poore and Ignorant of some princeples of religion" (65-66). On certain occasions, she works, with Rhodes and her other religious and social relations, to convince her neighbors of matters of godly concern. On March 11, 1599/1600, she writes of a visit with "some of my neighbours, with whom I took occasion to speak of divers nedfull dutes to be knowne: as of parence Chousinge for their children, of the charge of godfathers, and of the first instructing of them" (107). On another, she declines an invitation "to be a witness at [Mr Daunie's] childes baptisinge ... in regard that my Conscience was not perswaded of the charge I was to undertake, nor Throughly taught touchinge the parvartinge the ende of witnesses from a christiane instetutione" (118). Her belief that the established church has perverted the original intentions of baptism leads her to "inquire more of this matter, god willinge, with the next faithfull devine, beinge loth to denie, if I may, any freind such a Curtesie." A few days later, she records that she "walked with Mr Hoby and Mr Rhodes and talked touchinge baptismie" (118). $3^{30}$ Her navigation of a controversial matter thus involves not only deference to a godly authority - she waits to inquire of the matter with a "faithfull" divine-but also a blend of informed conversation and socio-political circumspection: the "freind" to whom she does not want to deny a "Curtesie" was a member of that

30. The entry continues, "Then I went to privat examenation and praier, havinge had a long rest now, I thank god, who, of his mercie, I pray to stringten me so in this releese that I may be prepared for new assaultes" (118-19). 
powerful, and recusant, local family: the Eures. ${ }^{31}$ The rituals she models resistance to, moreover, are among those practices of the established church most frequently attacked by Presbyterian-minded Puritans. Hoby's reading and discussion is thus best understood as a form of local Puritan activism, mediated by factors ranging from neighborliness to "Conscience"-keeping.

Effective Protestant proselytizing relied, as one polemicist put it, on "able ministers over the land, applying themselves in every case of conscience, as godly casuists unto all the distressed in mind." 32 While the Protestant ecclesiastical establishment certainly sought to make local ministers into more learned and abler instructors of their congregations, the means by which the Reformation was sought-lectureships, sermons, books, conversations - were both actively dialogic and deeply partisan. 33 And they could not be effected by the ministry alone. If, as Claire Cross has suggested, the success of Protestantism in England relied on the alliance of lay people with the clergy, then Margaret Hoby's relationship with Richard Rhodes is an exemplary instance of such an alliance-a partnership deeply affected, moreover, by its recusant northern context. 34 As with her other co-readers, Hoby's relationship with Rhodes is neither exclusively personal nor unidirectional (he no more "directs" her reading than she does his), and its ends are simultaneously devotional and doctrinal, partisan and dialogic, critical and communal. 35 Hoby may well have sought to counsel the "distressed in mind," but she also sought to affect what people believed and what they read. Indeed, her diary is a record of her relentless efforts not only to battle Catholicism but also to change how Protestantism was lived and practiced in England-particularly in ways that were critical of the Church of England. While Hoby certainly concerns herself with Catholics and "the good of the paritioners" (102) she also seeks to change people's ideas about the "princeples" of religion, and to introduce Puritan books into her

31. See Meads, Diary, 264 n. 337.

32. W. Loe, Vox clamatis (1621), 30, quoted in Keith Thomas, "Cases of Conscience in SeventeenthCentury England," in Public Duty and Private Conscience in Seventeenth-Century England. Essays Presented to G. E. Aylmer, ed. John Morrill, Paul Slack, and Daniel Woolf (Oxford, 1993), 29-56 at 37.

33. On the education of the ministry, see Peter Marshall, The Face of the Pastoral Ministry in the East Riding, 1525-1595 (York, U.K., 1995), 14. Cross notes that the central government was much more tolerant of Nonconformity in the north because of the struggle against recusants there and permitted the continuing education of clergy in Yorkshire when it was prohibited elsewhere; The Puritan Earl, 259.

34. Claire Cross, Church and People: England, 1450-166o (1976; repr., Oxford, 1999). For contrasting views of relationships between clergy and laywomen in the period, see Diane Willen, "Godly Women in Early Modern England: Puritanism and Gender," Journal of Ecclesiastical History 43, no. 4 (1992): 561-80; and Patrick Collinson, “'Not Sexual in the Ordinary Sense': Women, Men and Religious Transactions," Elizabethan Essays (London, 1994), 119-50.

35. In an essay on Hoby's marginalia that appeared while this essay was in the final stages of production, Andrew Cambers sees Rhodes as Hoby's director and considers the diary as "part of the regime of self examination which Richard Rhodes brought to her as chaplain." "Readers' Marks and Religious Practice: Margaret Hoby's Marginalia," in Tudor Books and Readers: Materiality and the Construction of Meaning, ed. John N. King (Cambridge, 2010), 211. 
community. ${ }^{6}$ The ways in which Margaret Hoby derived religious principles from texts and communicated them in the course of seemingly social transactions complicates our presumptions about the function and use of women's reading, and challenges the often reductive ways in which we understand women's "spiritual" activities. 37

\section{Reading de Mornay}

\section{[T] his after none, [I ] tooke a Lecture of Rhetorick -Diary of Lady Margaret Hoby}

Historians of the book and of reading often assert that women's reading was confined to the bedroom, or, in a sense that often misunderstands the functions of those spaces for women, to the closet. ${ }^{38}$ While some contemporary commentators describe early modern women reading "lap books," a term that might suggest a private and eroticized practice, books that were designed to lay open, whether in the lap or elsewhere, were in fact often meant for communal, public, and/or contestatory reading. 39 (For a famous representation of women reading "lap books" in a public and communal context, see the title page of Actes and Monuments [figure 1], which features women listeners seated below the pulpit, with books open on their laps). Indeed, when Alice Smith of Alderton bequeathed Ann Man a Bible in her 1624 will, she also left her a desk to use it on,

36. On the next day, a Sunday, Hoby makes the following entry: "After dinner I talked with some of my neighbours, that Came to me, tell church time: then, after the sarmon, I dresed other poore folks, and then, after order taken for supper and some talk with Mr Rhodes touchinge some of his flock, I went to privat praier" (102).

37. James Daybell similarly challenges the tendency to see early modern women's and men's sociability outside the home as qualitatively different, pointing out that "Whereas women are traditionally seen as 'gossips,' peddlers of ephemeral and trifling tittletattle, men are described as 'intelligencers,' suppliers of information of serious import"; "'Suche newes as on the Quenes hye wayes we have mett': The News and Intelligence Networks of Elizabeth Talbot, Countess of Shrewsbury (c. 1527-1608)," Women and Politics in Early Modern England, 1450-1700, ed. James Daybell (Aldershot, U.K., 2004), 114-31 at 116.

38. According to Kevin Sharpe and Steven N. Zwicker, until the Enlightenment opened things up, men read at desks, "women readers, by contrast, retired with the book to the intimacy of the closet." "Introduction: Discovering the Renaissance Reader," in Reading, Society and Politics in Early Modern England, ed. Kevin Sharpe and Steven N. Zwicker (Cambridge, 2003), 1-40 at 15. For women's closets as private and eroticized reading spaces, see Heidi Brayman Hackel, “'Boasting of Silence’: Women Readers in a Patriarchal State," in Reading, Society and Politics, 101-21. In her later work, Brayman Hackel revisits this claim, suggesting that bedchambers and closets were "frequently communal, even noisy, places"; Reading Material in Early Modern England: Print, Gender, and Literacy (Cambridge, 2005), 34 .

39. For the idea that women read with books in their laps, not on desks, see Brayman Hackel, Reading Material in Early Modern England, 207. For eroticized views of women's readings, see Sasha Roberts, "Shakespeare 'Creepes into the Womens Closets about Bedtime': Women Reading in a Room of their Own," in Renaissance Configurations: Voices/Bodies/Spaces, 1580-169o, ed. Gordon McMullan (New York, 1998), 30-63. For the extent to which lap books were, in fact, public books, see Margaret Aston, "Lap Books and Lectern Books," in The Church and the Book, ed. R. N. Swanson (Woodbridge, U.K., 2004), 186. 
suggesting (or encouraging) scholarly and communal reading. $4^{\circ}$ Not only did women read in a wide range of locations, but women's closets, like men's, served a variety of functions, including providing a place for scholarly transactions. William Sherman calls personal libraries "privy" rather than "private" spaces, "less asocial and apolitical than selectively social and political." 41 The same can and should be said of women's closets-and of their reading.

The extant records of early modern women's closet reading describe it as both non-scholarly and scholarly, and both private and privy. While many of these records are eulogistic and hagiographical, they nonetheless testify to a recognition of the range of women's reading practices. When Lady Elizabeth Cooke died in 166o, for example, her chaplain, Edmund Barker, wrote that "Her closet was not (as too many ladies' are) an exchange only of curious pictures and or rare and costly jewels, but a private oratory (as it were) cheifely designed for prayer and devotion." It was very seldom, he writes, "if ever that I found her alone there without a Bible before her." 42 Lady Frances Hobart's closet, "that she might want no satisfaction to any doubt arising upon her reading the Scripture," was reportedly "furnished ... with a large Library of English Divines ... of which she made daily use," and Hobart's sister, in turn, was never "more in her element, than when by debate with others she was sifting out some truth, in order to the further information of her judgement, or guidance of her practice." 43 If it is possible to see Frances Hobart's "daily use" of English divines as a private means of answering doubts about her Bible reading, her sister's practices of "sifting out" truths and "debat[ing] with others" indicate the means by which most theologically, doctrinally, and intellectually engaged readers worked: dialogically and contentiously.

40. On this bequest, see Kenneth Charlton, Women, Religion and Education in Early Modern England (London, 1999), 186. In the inventories included in Yorkshire Probate Inventories 1542-1689 (ed. Peter C. D. Brears, Yorkshire Archaeological Society Record Series 134 [Kendal, U.K., 1972]), Bibles and books are listed in a wide variety of public spaces, including "in the hall house," and, more interestingly, "in the milkhouse" $(68,97)$.

41. See Sherman, John Dee: The Politics of Reading and Writing in the English Renaissance (Amherst, Mass., 1995), 50. On women's closets as, among other things, places of scholarly transactions, see Lena Orlin, “Gertrude's Closet," Shakespeare-Jahrbuch 134 (1998): 44-67, and Aaron Kunin, "From the Desk of Anne Clifford," English Literary History 71 (2004): 587-608.

42. See Charlton, Women, Religion and Education in Early Modern England, 17o. In a letter to his sons, Sir Kenelm Digby praised his wife Venetia's reading of godly books “which she ruminated and digested at leisure, as it appeareth by her books of notes written in her own hand" (176).

43. John Collinges, Par Nobile. Two Treatises, The one concerning the Excellent Woman, Evincing a person Fearing the Lord, to be the most Excellent Person: Discourses more privately upon occasion of the Death of the Right Honourable, the Lady Frances Hobart, late of Norwich ... The other ... the Lady Katharine Courten (London, 1669), 272; see also Brayman Hackel, Reading Material in Early Modern England, 2-7. The closet of Mrs. Anne Sadleir, to take another example, was not only full of commentedupon books, but it was also a site of religio-political resistance, according to a 1646 poem addressed "To a Vertuous and Judicious Lady, who (for the exercise of her Devotion) built a Closet, wherein to secure the most Sacred Booke of Common-Prayer, from the view and violence of the Enemies thereof, the Sectaries and Schismatiques of this Kingdome”; quoted in Hunt, "Mrs. Anne Sadleir," 211-12. 


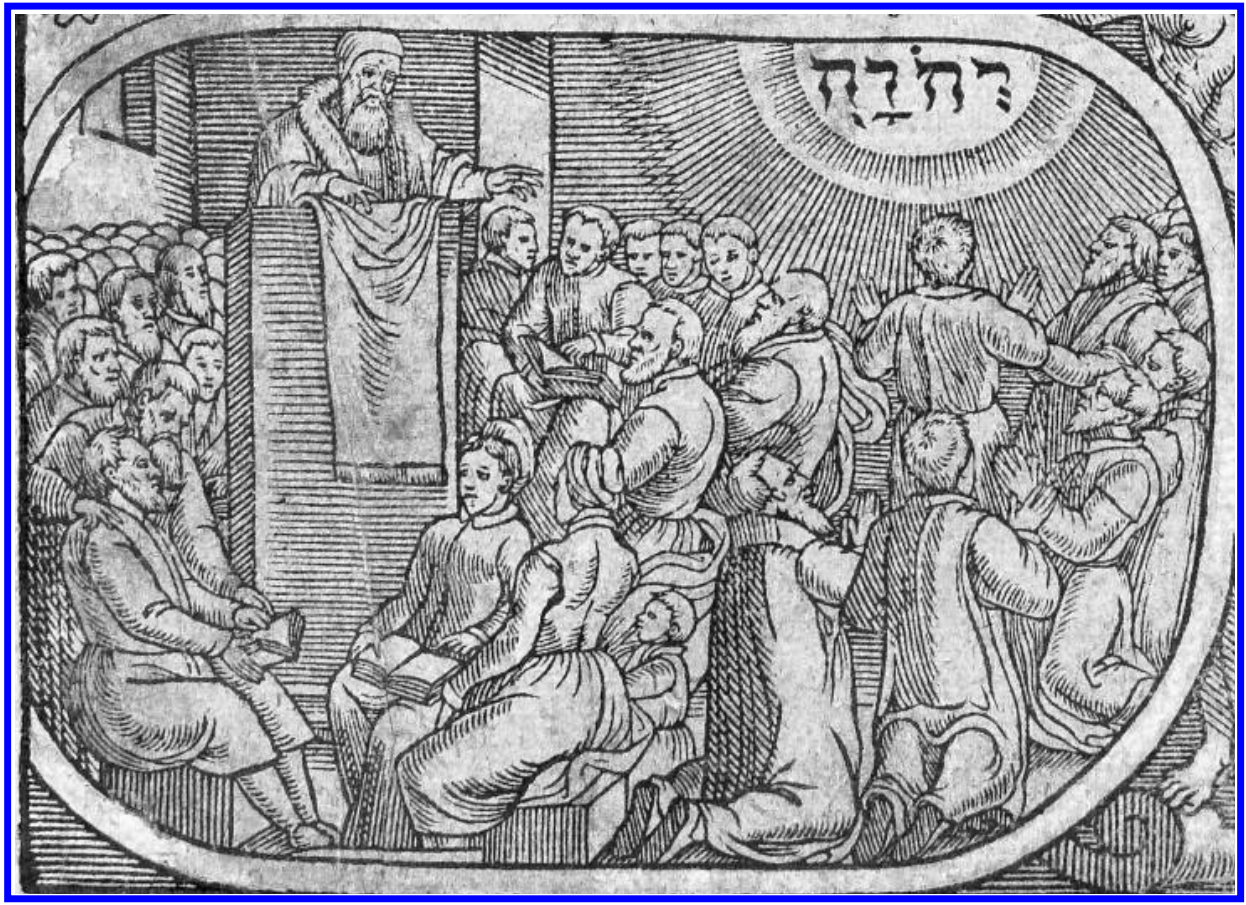

FIGURE 1. Detail from the title page of John Foxe, Actes and Monuments (London, 1653). Huntington, 59840.

The tendency to see women's spiritual reading as domesticated and somehow in keeping with women's subordination is thus a mischaracterization of the nature of such reading. The title of one excellent anthology on the subject, Silent but for the Word, suggests that women's engagement with religious texts was something of a paltry exemption to their generalized restriction from intellectual tasks and pleasures. 44 In the introduction to one recent anthology on reading, the authors write that "for most literate women the experience of the book was confined to spiritual genres and to household manuals." 45 Men, in other words, read for the "vita activa," and "women's reading ever re-inscribed them within domestic circumstances and spaces." 46

44. The full title of the anthology is Silent but for the Word: Tudor Women as Patrons, Translators, and Writers of Religious Works, ed. Margaret P. Hannay (Kent, Ohio, 1985). For more recent work on women's spiritual reading, see "Travailing for the Lord": Women and Religious Writing, 1500-1625, ed. Micheline White (Aldershot, U.K.: Ashgate, forthcoming).

45. Sharpe and Zwicker, "Introduction," 13, my emphasis.

46. Ibid. For an instance of the common, often unsupported, assertion that women's reading was leisure reading, see Paul Morgan, "Frances Wolfreston and 'Hor Bouks': A Seventeenth Century Woman Book-Collector," The Library, 6th ser., 11 (1989): 200. 
Yet to read, translate, and circulate religious texts was hardly an apolitical enterprise. The reading and use of spiritual texts was a fraught form of religious, intellectual, and political negotiation: ministers were killed for seditious would-be sermons that existed only in notes; people were arrested for reading Catholic books in their homes; Philip and Mary Sidney read, translated, and circulated de Mornay's texts as part of their critique of Elizabeth's policies on international Protestantism. 47 "Spiritual" reading, in other words, was not simply a means of keeping women chaste, silent, and obediently uninvolved in the wider world. Like the claim that women's reading was merely "ornamental," the assumption that women's reading was private, domestic, and spiritual and (therefore) neither contestatory nor goal-oriented is more a critical fiction than a reflection of historical practice. ${ }^{48}$ As William Sherman points out, "[John] Dee's base of operations was his own household, and his textual activities were carried out alongside his domestic and communal duties." 49 The same is true of Margaret Hoby. The characterization of Hoby's diary as being chiefly concerned with her "private" and "domestic" life (much attention has been paid to her "nursing" duties) is not only driven by ahistorical ideas about what a household is and what domestic work looks like, but it also misses the full complexity of the story that Margaret Hoby's diary, and her reading more generally, has to tell us. As Margaret Hoby's case makes clear, women, like men, read in scholarly and goal-oriented ways; we simply have to unearth those practices.

The wide range of books that Hoby mentions reading, with a great variety of co-readers, suggests the extent to which Margaret Hoby used books both to prepare for argument and as a local form of activism. ${ }^{\circ}$ She records, for example, reading the Bible (82) and the "book of Marters" with the men and women in her household (74, 75); the "diatt of the soule" (68) by the Yorkshire-based anti-Romanist and former chaplain to the Earl of Huntingdon, Thomas Morton;51 "a sarmon of [John] Udale," the Puritan controversialist and Huntingdon protégé; the work of the former Sidney/

47. Edmund Peacham, a Somerset rector, was pressed to death for his sermon notes. See Godfrey Davies, "English Political Sermons, 1603-1640," Huntington Library Quarterly 1 (October 1939): 1-22 at 8. On the Sidneys' use of de Mornay, see Margaret P. Hannay, "'Doo What Men May Sing': Mary Sidney and the Tradition of Admonitory Dedication," in Hannay, Silent but for the Word, 149-65. For more on the uses of de Mornay, see Patrick Collinson's ODNB entry on Thomas Wilcox.

48. For instances of this assumption, see David Cressy, Literacy and the Social Order: Reading and Writing in Tudor and Stuart England (Cambridge, 1980), 128; and Anthony Grafton and Lisa Jardine, From Humanism to the Humanities: Education and the Liberal Arts in Fifteenth-and Sixteenth-Century Europe (London, 1986), especially "Women Humanists," 29-57.

49. Sherman, John Dee, 69.

50. De Mornay is never mentioned in Hoby's diary, but her investment in his work is related to many of the most important relationships in her life: the family in whose house she was raised, the Earl and Countess of Huntingdon, and her first two husbands, Walter Devereux and Thomas Sidney, were all supporters of the Huguenots, and the reading and circulation of de Mornay's work, as I mentioned earlier, was central to their Protestant activism.

51. The full title is Two Treatises Concerning Regeneration, 1. Ofrepentance, 2. Of the diet of the soule shewing the one, how it ought to be sought after and may be attained vnto, the other, how it being gotten, is to be preserued and continued (London, 1597). 
Herbert chaplain, Gervase Babington (77); a book by "Mr [Hugh] Browghton," an antiWhitgiftian theological controversialist (114, 263 n. 326); the Whitgift and Cartwright disputation, with her minister, Richard Rhodes, and her husband (67, 97); "a good man's book" who "proveth" truths against the arguments of the anti-Puritan Thomas Bilson, bishop of Winchester (97, 259 n. 282) with Rhodes (this book may well be by the above-mentioned Hugh Broughton, as he was one of Bilson's sharpest critics); the writings of the Puritan William Perkins $(87,97,101)$; the work of George Gifford, another opponent of Whitgift and renowned godly preacher $(68,72)$, both by herself and with Rhodes; the works of the Puritan Richard Greenham with at least six others; and a variety of pamphlets, books, and manuscripts loaned or given to her by her cousin, her minister's wife, and a fellow Northern Puritan woman. ${ }^{2}$

Books, as William Sherman reminds us, conferred power and argumentative force "through the authority invoked in the reference." 53 While reading aloud and together could, as Roger Chartier has argued, "unite people around a book [and] foster convivial social relations," it could also be a form of negotiating power: reading aloud elicited commentary, criticism, discussion, and debate. Discussions among friends, moreover, "could attract others-silent auditors-instructed through listening to the texts being read or the exchange of arguments." If reading could be an articulation of "one person's rapport with others," that rapport, no matter how friendly, was nonetheless deeply imbued with power. 54 Books, in other words, were carriers of relationships, but they were also tools of negotiation.

When Lady Anne Clifford's eulogist writes that her Bible was her constant companion, pointing out that "when persons, or their affections, cannot so well be known by themselves, they may be guessed at by their Companions," he highlights the extent to which books were used as a rhetorical strategy through which people, or their flatterers, sought to establish their position in society. 55 Aemilia Lanyer similarly flatters Margaret, Countess of Cumberland and her daughter, the future Anne Clifford, by referring to their practices of "skan[ning]" and meditating on the Bible and other learned books, as well as sharing them with their "pined brethren, when they stood in need." 56 Through books people sought to make alliances, advertise their learning and connections, and to influence the terms of a debate or the direction of a

52. Hoby mentions a book Rhodes's brother Edward brought to her "from his wife" (April 23, 1601; 169). I will discuss the Northern Puritan woman, Isabel, Lady Bowes, further below. For a full list of the texts Hoby reads, see the appendix to Mary Ellen Lamb's essay, "Margaret Hoby's Diary: Women's Reading Practices and the Gendering of the Reformation Subject," in Pilgrimmage for Love: Essays in Early Modern Literature in Honour of Josephine A. Roberts, ed. Sigrid King (Tempe, Ariz., 1999), 63-94.

53. Sherman, John Dee, 73.

54. Chartier, "Leisure and Sociability: Reading Aloud in Early Modern Europe," Urban Life in the Renaissance, ed. Susan Zimmerman and Ronald Weissman (Newark, Del., 1989), 104, 107, 117.

55. Edward Rainbow, A Sermon Preached at the Funeral of the Right Honorable Anne Countess of Pembroke, Dorset and Montgomery, Who died March 22, 1675/6 (London, 1677), 61. On the use of books as a rhetorical strategy, see Sherman, John Dee, 50.

56. “The Description of Cooke-ham," in The Poems of Aemilia Lanyer. Salve Deus Rex Judaeorum, ed. Susanne Woods (Oxford, 1993), 161. 
conversation. 57 Indeed, some avid women readers were represented as skilled polemicists who sought to "promote and advance religion in others, not only by counsel, conference, admonitions, [and] exhortation," but also by giving them the right kind of books. ${ }^{8}$ Both Mary Rich and Anne Clifford, for example, were reputed to have disseminated religious books for their servants and visitors to read. 59

Although many of these examples are eulogistic, if not hagiographic, Margaret Hoby's reading habits are recorded in her diary as actual daily practice. This, however, does not mean that those reading practices were unremarkable, nor that they were geared primarily toward Hoby's personal edification and salvation. The diary's most recent editor points out that Hoby's extensive reading shows that she was "intellectually engaged in some of the most controversial theological issues of the day." Yet most people still see the diary as private, "kept largely as a means of assisting in the religious exercise of self-examination," or "a collection of private meditations and secret recollections." 60 In contrast, I argue that Hoby's diary, alongside the traces of her reading in de Mornay that I discuss below, suggests that Hoby's engagement with "controversial theological issues" was more than merely "intellectual." More precisely, I argue that her intellectual work-as intellectual work was for men-was "profitable to the exercise of government," or, at the very least, an integral part of the activities of those who "jostl[ed] for power." ${ }^{11}$ If it is now clear to us that reading Livy-a very dead Roman author-and talking about that reading with people of influence could have an direct effect on practical politics, it should be possible to understand the ways in which the communal reading practices of a Puritan woman in recusant Yorkshire were a form of social, religious, and political action. If earlier critics saw Hoby's reading and diary keeping as part of the "self-imposed career" of a "Puritan saint," I am more interested

57. On the relationship between reading and sociability, see Chartier, "Leisure and Sociability"; on the relationship between bookbuying and circulating, reading, and sociability, see Jason ScottWarren, "News, Sociability, and Bookbuying in Early Modern England: The Letters of Sir Thomas Cornwallis," The Library, 7th ser., 1 (December 200o): 381-402; and "Reconstructing Manuscript Networks: The Textual Transactions of Sir Stephen Powle," Communities in Early Modern England: Networks, Place, Rhetoric, ed. Alexandra Shepard and Phil Whithington (Manchester, U.K., 200o), $18-37$.

58. Charlton, Women, Religion and Education in Early Modern England, 200.

59. Charlotte Fell Smith, Mary Rich, Countess of Warwick (1625-78): Her Family and Friends (London, 1901), 172; quoted in Brayman Hackel, Reading Material, 66. On Anne Clifford, see Rainbow, Sermon Preached at the Funeral of the ... Countess of Pembroke, 33-34.

6o. Meads, "Introduction," 47; Moody, "Introduction," xv. For accounts of the diary as primarily an exercise in the Puritan discipline of self-examination, see the new ODNB entry on Margaret Hoby, by Paul Slack, and Mary Ellen Lamb, "Margaret Hoby's Diary," 64. Our reading of the Hoby diary is predisposed by our ahistorical expectations for diaries, that they should reveal thoughts and feelings; see for example McKitterick, "Women and Their Books," 366 and Meads, Diary, 267 n. 356. For a more thoughtful set of reflections on what a diary was-less a transparent reflection of actual events and feelings, than a genre with its own conventions and mediations-see Kunin, "From the Desk of Anne Clifford."

61. Jardine and Sherman, "Pragmatic Readers," 102, 106. 
in it as testament to a very public career. ${ }^{62}$ If silence was supposed to be women's most "moving rhetoricke," moreover, I am particularly interested in why Margaret Hoby, the "private" Elizabethan gentlewomen, on two occasions in May 1601 "took a lecture in Rhetorick," the art of public persuasion and influence $(172,173){ }^{63}$

Many of the books Hoby records reading in her diary have a pedigree affiliated with Puritan Presbyterian activism of the 1570 s (such as the debate between Thomas Cartwright and Whitgift) and the 1590s, and her reading of these books is frequently, even aggressively, communal. One particularly telling example of this is Hoby's often intently sociable reading of Richard Greenham, a Puritan defier of Whitgift's articles and defender of Cartwright whose 1599 Works were dedicated to Hoby's Puritan patron, the Countess of Huntingdon. His Works, moreover, were specifically associated with the proper reading and teaching of Puritan texts and doctrine. ${ }^{64}$ While her diary records a number of occasions on which she "reed[s] of Greenhame" alone (69, 71), she also records others reading him to her: Margaret Rhodes, a relative of her chaplain (85), Rhodes himself (86), "Averill," another member of her household and, not coincidentally, the daughter of the Yorkshire High Sheriff, 65 the visiting preacher "Mr Ardington" (142-43), to whom I will return shortly, and an influential local landowner, Mr. Stillington (168).

62. The first quotation is from Sara Heller Mendelson, "Stuart Women's Diaries and Occasional Memoirs," Women in English Society, 150o-180o, ed. Mary Prior (London, 1985), 181-210 at 189, the second from Diane Willen, "Godly Women in Early Modern England: Puritanism and Gender," Journal of Ecclesiastical History 43 (1992): 561-80. See also Peter Lake on Jane Ratcliffe of Chester and the "cult of personal godliness." "Feminine Piety and Personal Potency: the 'Emancipation' of Mrs. Jane Ratcliffe," Seventeenth Century 2 (1987): 143-65 at 155, and Michael Winship, "Bridget Cooke and the Art of Godly Female Self-Advancement," Sixteenth Century Journal 32 (2002): 1045-59. Winship argues for the importance of the semi-public venue of the conventicle to lay Protestants in England, including women (1046). The conventicle or its approximation, as we will see shortly, is equally important for Margaret Hoby.

63. The quotation, "Silence in a woman is a moving rhetoricke, winning most when in words it wooeth least," is from Richard Brathwaite, The English Gentleman; and the English Gentlewoman (London, 1641). Meads suggests that Hoby was perhaps reading Thomas Wilson's The Arte of Rhetorique (1552) (Diary, 279 n. 466), but in the entries she uses the verb "took" (as in "I tooke a Lecture of Rhe;") suggesting, at the very least, an active lesson. Regardless of the exact form it took, Hoby's study of rhetoric was, as I argue further below, intimately related to her communal reading practices.

64. On Greenham, see Eric Carlson's entry in ODNB, and Paul S. Seaver, The Puritan Lectureships: The Politics of Religious Dissent, 1560-1662 (Stanford, Calif., 1970), 218-19. Mary Ellen Lamb points out that Greenham, like William Perkins, was "at the forefront in the Protestant movement to apply abstract doctrine to the practices of everyday life," and sees Hoby's reading of him as part of this discipline ("Margaret Hoby's Diary," 68). My work suggests that Hoby had a further- and more outwardreaching kind of reading practice.

65. Everill Aske was the daughter of the Yorkshire High Sheriff from 1588 (see Meads, Diary, 256 n. 246). Lamb sees Aske and Hoby as forming a network of gentlewomen, but while she sees it as a "female subculture" ("Margaret Hoby's Diary," 78), I see the women's reading as part of a wider vision of religio-political influence. Like the Countess of Huntingdon, Hoby did take many young women into "service" in her household. 
Indeed, Hoby's presentation of this last readerly transaction- "I Came home and Caused Mr Stillington to Read of Grenhame" (168, emphasis mine)-indicates the ways in which she creates a community of readers around a text: not just though her household and amenable visitors, but through a kind of willful interpellation. ${ }^{66}$ The "Preface to the Reader" in Greenham's Works opens with Proverbs 10:21, "The lippes of the righteous feede many," but warns that those lips should not want the "art and good experience" of holy books and learning. In order to minister to others, one must "know how to proceede by any certaine rule of art, and well grounded practice." 67 Through "causing" others to read Greenham's work with her, Hoby in fact enacts the kind of practice Greenham encourages, enabling both herself and her wider community to come prepared for any dialogue on religion, "the want of which," in Greenham's words, "maketh much janglings and wranglings in companie" (394). Margaret Hoby used Greenham in the same way she used many other books, sermons, and discussions: to shift local religious conversation in the direction of Presbyterian-minded Puritanism, keeping books and beliefs alive that had, according to most historians, gone "underground" for much of the period during which Hoby kept her diary. ${ }^{68}$ The diversity of her co-readers and discussants, who ranged from local women and landowners to representatives of the local ministry and magistracy, suggests the extent to which she sought to normalize this critical tradition and promote its reformist ends through the use of books.

A number of books owned and signed by Margaret Hoby and her husband Sir Thomas Posthumous Hoby survived in the Hackness parish library, now part of the York Minster Library. The vast majority are works of religious controversy. Those signed by Sir Thomas include one of John Whitgift's responses to Thomas Cartwright's Second Admonition to the Parliament, an edition of Foxe's Acts and Monuments, a translation of Calvin's Institution, and Thomas Morton's A Catholike Appeale for Protestants (1610). ${ }^{69}$ The books signed by Margaret Hoby are John Donne's notorious

66. On Robert Stillington, see Robert Glover, The Visitation of Yorkshire, made in the years 1584/5, by Robert Glover, Somerset herald, ed. Joseph Foster (London, 1875), 633. Hoby is carefully sociable with the Stillingtons, talking with his wife, and, on October 30, 1601, "sett[ing] some trees which Mr Stillington sent me" (Diary, 190).

67. The VVorkes of the Reuerend and Faithfull Seruant of Iesus Christ M. Richard Greenham, minister and preacher of the word of God (London, 1599), edited by Henry Holland. A4, A4v. All subsequent references will be cited parenthetically in the text.

68. The standard account of the movement remains Patrick Collinson, The Elizabethan Puritan Movement (London, 1967).

69. John Whitgift, The Defense of the Aunswere to the Admonition, against the replie of T. C[artwright] (London, 1574), York Minster Library (YML), shelfmark: Hackness 45; John Foxe, Actes and Monuments of Matters Most Speciall and Memorable, Happening in the Church, 7 th ed. (London, 1610), YML, Hackness 2 (1). John Calvin, The Institution of Christian Religion ... translated into English ... by Thomas Norton (London, 1611), YML, Hackness 19, and Thomas Morton, A Catholike Appeale for Protestants, out of the Confessions of the Romane Doctors (London, 1610), YML, Hackness 51. The other books signed by Sir Thomas are John White, VVorkes (London, 1624), YML, Hackness 42; Thomas Morton, Of the Institution of the Sacrament of the Blessed Bodie and Blood of Christ (London, 1631), YML, Hackness 44; Edward Coke, Quinta pars relationum Edwardi Coke Equitis aurati (London, 
Pseudo-martyr, a 1606 edition of the Puritan activist John Field's translation of Philippe de Mornay's A Treatise of the Church, and a heavily annotated copy of the 1600 translation of de Mornay's Fowre Bookes, of the Institution, Use and Doctrine of the Holy Sacrament of the Eucharist in the Old Church.$^{70}$

It is this final book, wholly concerned with the central Christian controversy, in which we see Hoby actively reading de Mornay. The extensive marginalia in Hoby's copy of this book are in Hoby's own hand-it matches her signature in the front of the book, as well as her handwriting in her diary. ${ }^{71}$ Marginal traces of women's reading are sufficiently rare that Hoby's should therefore be recognized as a key site for the study of early modern women's reading practices. ${ }^{72}$ I want to suggest that it is as important that marginalia in the book exist under her aegis (the signature "Margaret Hoby, 1600") and thus that the best way to think about marginalia is less as traces of individual reading than as traces of reading under a name-of a person, a family, a household, a faction, a cause. Hoby's diary reveals that she read books signed by her husband, reminding us that signs of ownership are not signs of exclusivity. 73 (The book she reads with Rhodes on December 28, 1599, "Mr Cartwright and the Bushoppe of Canterberies booke" [99], is one of those bearing her husband's signature.) As the wide range of Hoby's reading partners testifies, quite a few people could have made marginal marks in Hoby's books, working in service of or in scholarly conversation with the woman who signed them and with the causes with which she was involved. The marginalia in Margaret Hoby's copy of de Mornay's Fowre Bookes testify, like the other communal reading practices recorded in the diary, to Hoby's active and critical reading with others. 74 But they also indicate something of the wider ends and purposes of this active reading.

1605), YML, Old Library XI I 10; Gerhard Mercator, Atlas sive Cosmographicae meditationes (Duisberg, Germany, 1595), YML, Old Library III A 8, and Abraham Ortelius, Theatrvm orbis terrarvm (Antwerp, 1592), YML, Old Library III A 4/2.

70. Donne, Pseudo-Martyr (London, 1610) YML, Hackness 57. Philippe du Plessis de Mornay, A Treatise of the Church, 2nd ed. (London, 1606), YML, Hackness 66; de Mornay, Fowre Bookes, of the Institution, Use and Doctrine of the Holy Sacrament of the Eucharist in the Old Church, 2nd ed. (London, 1600), STC 18142, YML, Hackness 47. On the controversy the latter attracted when it was published, see Mark Pattison, Isaac Casaubon, 1559-1614 (London, 1875), 153. See also Peter Milward, Religious Controversies of the Elizabethan Age: A Survey of Printed Sources (London, 1978), 139-41. References to Hoby's marginalia in the pages of Fowre Bookes will be given in the text.

71. Deirdre Mortimer, curator of rare books, and Peter Young, paleographer and curator of manuscripts, both at the York Minster Library, also believe the marginalia to be Hoby's. See also Cambers, "Readers' Marks and Religious Practice: Margaret Hoby’s Marginalia."

72. For the observation that early modern women were generally "silent" readers, who refrained from annotating the books they signed, see Brayman Hackel, "Boasting of Silence,"” 101, 107.

73. Brayman Hackel notes that "ownership marks, which seem to be competing for possession of the book, suggest a fluidity of ownership and access within a household" (Reading Material, 161). Since readers may contribute to marginalia even when they do not write them themselves, marginalia in books in family libraries, even when not linked paleographically to a given woman, thus may testify to women's reading.

74. On annotation practices, see Brayman Hackel on Lady Anne Clifford, who both wrote and dictated her marginalia (Reading Material, 49). 
In "The Preface of the Author upon this Second Edition" of $A$ Treatise of the Church (1606), a book signed but not annotated by Margaret Hoby, Philippe de Mornay acknowledges both the controversy that greeted the original publication of this work, and the selective ways in which people read. Readers would have done better, he insists, "to follow this Treatise (as they were required) from reason to reason, and from page to page" (Bv). De Mornay's desire that the reader follow his book from "reason to reason," or argument by argument, in sequence, seeks an intimate readerly study not only of the text he has written, but also with the texts he has cited or from which he has taken his evidence. What he encourages, then, is not only a thoroughgoing reading of the range of learned opinion on church history, including his own, but also an active, comparative engagement with it. In his epistle "To the Reader" de Mornay asks the reader to read not as one "hauing already found the truth, but as one that seeketh after it," and asks those who need clarification to "set it downe in writing, and by the grace of God we shall endevour to cleare the same"; he further advises those who condemn it "to answere it point by point, and reason by reason, in the spirit of sinceritie and mildnesse, seeking ... the salvation of the people" (B2). He asks, in other words, that people read and take notes not only with a greater cause in mind- "the salvation of the people"-but for the purposes of clarification, dialogue, and argument. I want to argue that in many ways Margaret Hoby follows these directions in her reading and annotation of de Mornay's book on the Eucharist.

In her diary, Hoby frequently records reading and taking notes in intimate relationship to each other. In addition to referring to manuscript books that have not survived, a "Common place book" $(67,81)$, a "book [of meditations?] framed by Mr Rhodes" (95), and a "sermon book" $(66,67,108)$, she makes numerous diary entries about writing notes in books as a record of or response to hearing sermons and reading other works. Most often she records writing "notes" in her "testament" $(64,68,71,75,76$, 77,79 , and passim) and Bible $(66,67,69,70$, and passim), but she also frequently characterizes her note taking as a record of multiple sites and forms of theological, doctrinal, scholarly, and intellectual exchange. For example, both "After privat praiers I wrett notes in my testement, which I geathered out of the Lector the night before" (70), and "I reed of the testemet, and wrett notes in itt and upon Perknes [William Perkins]" (101), suggest a comparative and intertextual process. Furthermore, rather than marking the end of her intellectual or theological engagement, the note taking seems to provide the basis for further engagement. Indeed, when Hoby writes on February 4, 1599, of going "to privat praier and examenation, then to supper, after to the lector : after that, to my Closit, where I praied and Writt som thinge for mine owne privat Conscience" (101), she points out the (much rarer) "privat" nature of what is usually for her a practice oriented toward further exchange with others.

As yet the only discovered substantive Hoby marginalia, the marginalia in Margaret Hoby's copy of de Mornay's Fowre Bookes seem to be in preparation for debate, which is wholly in keeping with her habitual practices of reading, note taking, and conversation. As a record of active reading, scribal marginalia could serve a number of 
purposes: they might correct, elaborate on, or otherwise engage with the text; identify difficult, ambiguous, or controversial claims; serve as a record of a dialogue, service, or training in adversaria; serve as a reference or guide for others' or the reader's own future readings; or mark places exemplifying a particular rhetorical maneuver or mode of expression which the reader sought to commit to memory, excerpt for commonplacing, and/or make use of in conversation or debate.75 (Mary, Countess of Warwick, for example, kept a book of apothegms in order that she might "suitably lard her conversation" with them, and Frances Wolfreston prefaced her copy of a querelle des femmes treatise with the phrase "in prais of women, a good one," suggesting she might have planned to use it in argument.) ${ }^{76}$ Marginalia, particularly those in religious texts, could be and were often used for polemical or disputational ends, and this is how I understand Hoby's marginalia in de Mornay's book on the Mass.

Hoby's marginalia call attention to contentious issues in Puritan controversy with an eye to recording and establishing the history of the primitive church and singling out its Romish corruptions. Her more pointed strategy, however, seems to have been to adduce strong proofs and points of argument in these matters of controversy. The most frequent marginalia highlight moments at which the corruptions most decried by reform-minded Protestants were first introduced into the primitive church: "four hundred years after Christe, or ever ye worde Masse was used" (33); "ye first occasion of using ye crosse" (49); "how ye table came to carry ye name of an altar" (109); and "how images firste got footinge in ye church" (121). She also notes (contested) points of Protestant belief-"sygnes have no other power than that which ye lorde giveth them" (161) - and occasionally emends de Mornay's own printed marginalia to make the $\mathrm{Pu}$ ritan view in a controversial matter crystal clear. For example, she adds to de Mornay's own marginal note indicating his topic, "The Priestlie garments," the words "which in ye oulde church were none but ordinary attire" (163).

Hoby is not averse to pointing out the inferiority of the Catholic Church ("ye church of Rome did not bringe forthe one doctor of note in ye tyme of all ye council informer ages" [44]), and indulges in the occasional mockery of its practices and beliefs. After underlining a number of benefits Catholics superstitiously believe the mass could achieve- "good for warres," "saveth cattell" - she adds a sarcastic marginal note, "St Gregoryes masse delivers soules out of purgatorye" (72), highlighting a belief that

75. On the polemical uses to which readers put marginalia, see Joad Raymond, "Irrational, Impractical and Unprofitable: Reading the News in Seventeenth-Century Britain," in Reading, Society and Politics, 185-212 at 185. On the influence of religious controversy on the practice, see Steven N. Zwicker, "Reading the Margins: Politics and the Habits of Appropriation," in Refiguring Revolutions: Aesthetics and Politics from the English Revolution to the Romantic Revolution, ed. Kevin Sharpe and Steven N. Zwicker (Berkeley, Calif., 1998), 101-15, Brayman Hackel, Reading Material, 31; Hunt, "Mrs. Anne Sadleir," 210. In Used Books: Marking Readers in Renaissance England(Philadelphia, 2008), William H. Sherman notes that literary texts were annotated less than texts associated with religious controversy (xiii).

76. On Warwick, see McKitterick, "Women and Their Books," 365. On Wolfreston, see Morgan, "Frances Wolfreston and 'Hor Bouks,"” 204. 


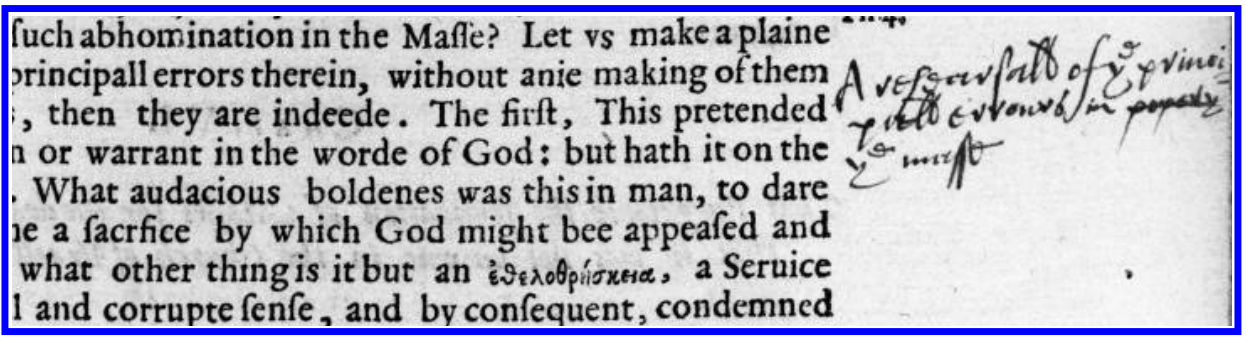

FIGURE 2. Detail of de Mornay, Fowre Bookes, 235, showing Margaret Hoby's marginal note. York Minster Library, Hackness 47. Reproduced by kind permission of the Dean and Chapter of York.

was a frequent target of Protestant criticism. 77 Yet while her marginal summaries of de Mornay's arguments are often judgmental, as in "muttering used by ye romish priests in ye consecration directly contrary to christs institution" (158), at times she edits her own marginalia to avoid sweeping condemnation of Catholicism as a whole.

In summarizing one section, for example, she originally wrote: "A rehearsal of ye principall errours in popery" but later crossed out the final word-a term not used by de Mornay or his translator-and amended her notation to "A rehearsal of ye principall errours in ye masse" (235, my emphasis; see figure 2). What is notable in this revision of her own marginalia is Hoby's precision, her desire to specify exactly what she is arguing against and about, and her resistance to her own urge to subsume points of doctrinal controversy, and thus of potentially fruitful engagement, under a sweeping term of opprobrium. This is not to say her marginalia avoid making judgments in excess of de Mornay's - she notes next to one description of a ritual, "ye grosse prayer yt is made att ye consecrating of ye crosse" (136), and "grosse" is not used in the text itselfbut rather to point out that they are often careful summaries of the matter and form of argument. ${ }^{8}$ Next to de Mornay's own printed marginal reference to 2 Kings 22:20, to take another example, she originally wrote "a good place to know tht ye saints know nothing done upon earth," but again edited her own marginalia to read "a good place to prove tht ye saints know nothing done upon earth" (305, my emphasis; see figure 3 ). In replacing "know" with "prove," Hoby indicates that her reading is intended not (or not only) for personal assurance or edification, but rather for argumentative communication, to prove a point to others via recourse to considered reading and engagement. Her use of the term "prove" suggests that she views de Mornay's explanation as an arsenal of argument, in keeping with a spiritual practice centered on preaching, disputation, and conversation.

Hoby's language in other marginal notes further indicates this argumentative end. She summarizes arguments using the terms "allegations" ("Allegations for Im-

77. On Protestant attacks on purgatory, see Stephen Greenblatt, Hamlet in Purgatory (Princeton, N.J., 2001).

78. She uses this term in another marginal note: "how grossly ye worde masse is translated \& drawne from its signification" (34). 


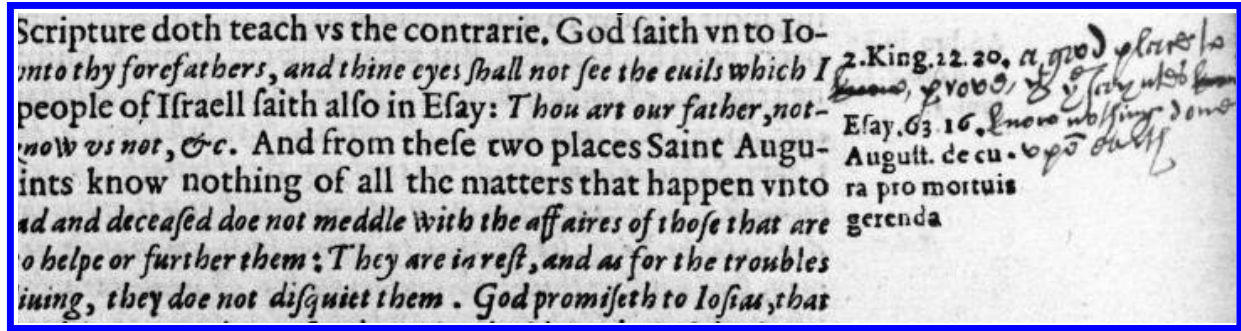

FIgURE 3. Detail of de Mornay, Fowre Bookes, 305, showing Margaret Hoby's marginal note. York Minster Library, Hackness 47. Reproduced by kind permission of the Dean and Chapter of York.

ages," "Allegations agaynste images, \& ye adoring of them" [129]), "answers" ("an answere to Gen. 14 and yt filthy stuffe which from ye falsification of that claim they bringe" [201]; "a good answere to ye popish shift of ye sayntes seeing our thoughtes in god" [304]); and "proofs" ("a proofe, yt Christe did administer ye cupp unto his disciples not as preistes consecratinge but as faythfull men" [93]). Indeed, this last "proofe" was a matter of particular concern for Hoby. In chapter 10 of Fowre Bookes, which argues "That the communion under both kindes [bread and wine] was practiced all in the old Church" (75), Hoby pays particular attention to the cup, adding to de Mornay's own printed marginal note, "The foolish reasons of the Councell," the words "why ye givinge ye cup to ye laity should be cutt of $[\mathrm{f}]$ " (89). While de Mornay mocks the reasons given by Catholics (the fear "That a licour may be shed" by laypeople's clumsiness), Hoby is more forceful in her judgment, condemning in the margin the "blasphemous councell of papists" who made the decision to keep the cup from the people (89). Hoby acted on the anger she expresses here in her marginalia in quite material ways. In October 1605 , five years after she signed the de Mornay title page, the Hobys gave to Hackness parish church "One Comunion Cupp with a cover weyinge $12 \mathrm{oz}$." a clear sign of their commitment to the communion under "both kinds." 79 If the bulk of Margaret Hoby's reading of de Mornay seems to be a page-by-page "study for argument," the gift of the cup seems to be an argument of a very particular kind, giving to the people of Hackness, much as de Mornay wanted, a communal means of Protestant salvation. ${ }^{80}$

Unsurprisingly, Hoby's marginalia frequently suggest criticism of the Elizabethan Prayer Book service and ecclesiastical hierarchy. Some of the most heavily annotated sections concern the ministry, and she takes particular care with the sections in which de Mornay outlines a pattern for the "generall agreement and consent of the people and ecclesiasticall order" about who was to "bee chosen Bishoppe or Elder"

79. See The Register of the Parish of Hackness, 1557-1783, transcribed by Charles Johnstone and Emily J. Hart (Leeds, U.K., 1906), 75.

8o. For Hoby, the most important aspect of the Mass-and one she underlined in de Mornay's text - is that it was: "an assemblie of Christians, calling uppon the name of God by Jesus Christ." It included "singing his prayeses, hearing his worde, [and] attending unto the expounding of the same, as it was delivered them by the Pastors" (52). 
(161, Hoby's underlining). In the margin next to a discussion of elders and deacons, she has written, "How bishops were chosen in ye oulde church," and on the next page, "bishopps in the firste ordination not above other ministers" (162). Indeed, her other readings support this critical judgment of the ecclesiastical hierarchy: on April 1, 1601, Hoby records in her diary that Rhodes read to her the argument "that no Callinge is lawfull with out a grown[d]e for itt in godes word: $2^{\circ}$, that the title of Lord Archbusshopes are Vlawfull" (166). Hoby also records hearing "Mr Rhodes read of the true diCeplen of christes church" (181), or the Book of Discipline, the surreptitiously circulated Presbyterian guidebook that outlined, among other things, the unlawfulness of bishops and the desirability of electing elders in a reformed church. ${ }^{81} \mathrm{Her}$ reading of de Mornay, in other words, was in keeping with her wider practices of reading, discussion, and argument - with "papests" and Protestants, and with those who conformed and those who sought further reformation.

\section{$\sim$ The Presbyterian Underground}

Like many propertied Puritans, Hoby carefully navigated between maintaining good relations with members of the established church and supporting its critics. Her diary records frequent visits with the dean of York and bishop of Limerick, John Thornborough, and his wife, and in her visits to London she takes care to be seen with Mrs. Thornborough at public places such as the Exchange and Lincoln's Inn. ${ }^{82}$ She makes frequent visits to the archbishop of York, Matthew Hutton, at Bishopthorpe (including a visit in which she "talked with Mrs Hutten of relegion" [73]). After visiting the home of the new lord president of the Council of the North, Lord Burghley, she is visited on the following evening in turn by his chaplain, Mr. Fuller, whom she evaluates as "a godly and relegous young man" (73). Yet these visits do not simply testify to an easy alliance of the gentry and the ecclesiastical establishment: both Hoby and the chaplain seem to understand that he is subject to her approbation. Indeed, Fuller's subsequent "Christian Conference" with Hoby, an exposition on a psalm, seems to be something of a job interview. ${ }^{83}$ And sometimes approbation was not forthcoming. Her judgment of William Palmer, the chancellor of York Minster from 1571 to 1605 , is

81. The Book of Discipline circulated, usually in manuscript, throughout the English countryside in the 1580 os and ' 90 . It was at St. John's College, where many of the men Hoby supports were educated, that the Book of Discipline was allegedly revised for the last time in 1589. On the Book of Discipline, see the ODNB for Thomas Cartwright and the chapter on the Book of Discipline in Collinson, The Elizabethan Puritan Movement, particularly 291-302. Hoby read or heard sermons by several ministers who subscribed to a survey indicting bishops presented to the 1586 parliament, including George Gifford, John Udall, Cartwright, Field, and Egerton.

82. On Yorkshire visits with the Thornboroughs, see, for example, Diary, 146, 147. During one of the London visits, on December 16,1600, Hoby goes with Mrs. Thornborough and her mother "in a Cotch in to the feeldes and there walked" (158); Moody guesses the area was Lincoln's Inn (Private Life of an Elizabethan Lady, 129 n. 229). On the 2oth she "went wth Mrs Thornborow to the exchang" (159).

83. On January 16, 1600, she was "vesited in the afternone wth fuller, wth whom I had good Christian Conference, how [sic] Expounded, [a psalm] unto me, and tould me his praier was to god that, in the actions of god which he was to perform, none of his owne affections might be mingled" (162). 
scathing: "I went to the church, wher I hardd Mr Palmer speak, but to small profitte to any" (73). ${ }^{84}$ His words, in fact, make her "lament the misirie of godes visible Church" (73). While Fuller passes inspection, that is, Palmer is found wanting, a sign of the "small profitte" a poor preacher-and the established church-offer the people.

Margaret Hoby records hearing and taking notes on the sermons and "disputations" of a wide variety of Yorkshire preachers, including those who were definitely not part of the ecclesiastical establishment. Her diary also records her frequent conversations with and judgments of these men. ${ }^{85}$ Often her readings and evaluations occur in sequence and within specific Puritan communities. The day after she "talked of good maters with Mr Maud," a St. John's-educated Puritan affiliated with the Wakefield Grammar School (a venue known for its Puritan library and teaching), she "hard one read of ardentons book" (88). ${ }^{86}$ This hitherto unidentified book is, I believe, the work of Henry Arthington. Arthington was a Yorkshire man, also from Wakefield, famous for his association with the executed Presbyterian William Hacket, and, according to his own published account, for being "a detector of Seminaries, olde massing Priestes, and Jesuits." 87 (Not coincidentally, the Arthington/Hacket case was used against Thomas Cartwright in 1591 when the Star Chamber was trying to determine if he was the author of the Book of Discipline, a book, as we have seen, that Hoby also read.) ${ }^{88}$ Hoby reads Arthington again on September 7, 1600 ("I reed of Mr Ardingtons booke" [143]), and "Ardington" reads to her March 28, 1601, and several times in August of the same year. (On the 5 th she records "hard Ardington read, and singe psa:" [181].) As we saw earlier, "Ardington" is also one of the men Hoby has read Greenham to her.

84. Hoby also criticizes the ungodly magistracy: "Mr pollard the Head Constable, dined wt us: stronge is the force of vanitie but the Lord is greater then all" (208).

85. For example, on April 10, 1600, Hoby went to the minster "wher I hard Mr Smith defend the truth against the papest, the question beinge whether the regenerate doe sinne: after I Came home I went to diner: I went to the church where I hard Mr Stuard handle this question between the papists and us - whether we were Iustefied by faith or workes" (113). Hoby makes the following entry for April 13, 1600: "I went to Mr Harwoodes sermon, in which he deliuered this faulse possi[t]ion, that, for necessetie, a minester might buye church liuinges, for necessetie had no lawe" (75). On October 26, 1599, she "hard a great disputation between 2: preachers" (80). Hoby frequently judged ministers based not on their positions in the church, but on their preaching and opinions. To take only two examples, "Mr Wilsone" is termed "a godly preacher," and Mr. Maude, an "exceedinge good Christian" $(78,88)$.

86. This is probably Edward Mawde or Maude, on whom see Ronald A. Marchant, The Puritans and the Church Courts in the Diocese of York 1560-1642 (London, 1960), 263; and J. Venn and J. A. Venn, Alumni Cantabrigienses, Part I: From the Earliest Times to 1751, 4 vols. (Cambridge, 1922-27). Like Rhodes, Mawde attended St. John. Following her first mention of "Maud," Hoby records talking "of good matters with Mr Rhodes and Mr Maude, a younge devine, a exceedinge good Christian," and, the following day, notes that she "hard Mr Maud read of a sarmon book" (89).

87. Henry Arthington, The Seduction of Arthington by Hacket especialie with some tokens of his vnfained repentance and submission (London, 1592), 42. Arthington was also the author of The Exhortation of Salomon (London, 1594), Principall Points of Holy Profession (London, 1607) and Prouision for the Poore, novv in penurie (London, 1597). On Arthington, see A. G. Dickens, "The Writers of Tudor Yorkshire," Transactions of the Royal Historical Society, 5th ser., 13 (1963): 49-76 at 63.

88. On the use of the Arthington/Hacket case against Thomas Cartwright in 1591, see ODNB entry for Cartwright. 
During the time Hoby is reading most actively with Arthington, she also records a series of engagements with one "Lady Bowes." Isabel, Lady Bowes was a fellow, and equally active, Northern Puritan woman. Like Hoby's, Bowes's husband was a member of the Council of the North and a devoted recusant-chaser. Bowes herself patronized Puritan and Nonconformist divines, provided venues for Puritan disputations and discussions in both Derbyshire and Yorkshire, and was an outspoken critic of the established church. Like Hoby, she was particularly active during the crucial years of the transition from Elizabeth to James. ${ }^{89}$ Margaret Hoby corresponds with Lady Bowes (on both August 14 and 17, 1601, she "wrett a letter to my lady Bowes" [183, 184]), and on November 10 she records "reed[ing] some meditations of the Lady Bowes hir Makinge" (191). That Bowes shared her unpublished manuscript with Hoby suggests that the two women shared a particular type of relationship, one as concerned with godly alliance and textual exchange as with personal edification. The fact that Hoby was reading Bowes's "meditations" at the same time as she was reading with the exiled Arthington further suggests that these practices of reading and communication were part of a regional activist movement.

Hoby's interest in Arthington-who, beginning in November 1601, "wintered" in the Hoby household (191) - Bowes, Maude, and Richard Rhodes testifies to her investment in radical, unbeneficed, and often divested, preachers: men educated at the Puritan Cambridge college that fostered the Book of Discipline and deeply committed to a more radical critique of the church than the average "church Puritan." Although she rarely recorded in her diary the subjects of the myriad sermons and conversations to which she was privy, those she did record were all matters of Puritan controversy that the archbishop of Canterbury feared were gaining purchase in the period, such as the lawfulness of bishops, the nature of grace, the means of justification. $9^{\circ} \mathrm{Her}$ reading, both of de Mornay and others, and her discussions with preachers about their ideas, moreover, empowered her in her judgments of and interventions in local religious politics.

Among other deprived ministers, the Hobys offered a place in their home to Richard Stainforth, the only Yorkshire minister Matthew Hutton ever deprived for Nonconformity. ${ }^{91}$ Margaret Hoby also ran community intervention for Richard Rhodes, who was on a number of occasions brought up for preaching in unsanctioned venues and without the Book of Common Prayer, and who would eventually be ar-

89. On Lady Bowes's role in local religious politics, see Christine M. Newman, “'An Honourable and Elect Lady': The Faith of Isabel, Lady Bowes," Life and Thought in the Northern Church, c. 110o-170o, ed. Diana Wood (Rochester, N.Y., 1999), 409, 413, 414.

90. See 90 (on grace), 114 (on justification). Hoby also records a sermon on the controversial practice of buying livings (113). On the archbishop's letter to Matthew Hutton expressing his concerns, see Hutton, Correspondence, 155 .

91. On Richard Stainforth, also a graduate of St. John's, see Marchant, The Puritans and the Church Courts, 26, 282. The Hobys also had frequent interactions with William Ward of Scarborough, who was eventually punished in 1604 visitation for refusing to wear the surplice (see Diary, 174, 219, 290); see Marchant, 290. Ward eventually became a member, along with Sir Hoby, of a commission for prosecuting recusants (Diary, 220). 
rested for holding illegal conventicles in his house. $9^{2}$ While Hoby records many examples of Rhodes co-reading with herself and the citizens of the East Riding, she also offers a brief record of the work she had to do to keep his expoundings within the boundary of the acceptable. On April 12, 1600, she had "speaches with Mrs fearne of Mr Rhodes, and how much she had mistaken him" (113). John Ferne, her interlocutor's husband, was a member of the Council of the North known to be more aligned with court interests in London than with local ones (113 n. 323). His appointment had been arranged by Robert Cecil, who in turn was reported to have laughed when William Eure mimicked Rhodes, "by using such gestures as his preacher did use in his evening exercises” (271). The Hobys' close connection with Rhodes may have deepened local hostility against them. Felicity Heal suggests that Rhodes was a motivating factor in the 1600 Eure and Cholmley attack on the Hoby household, noting that "Lady Margaret's waiting woman suggests that [William Eure] was deliberately hunting for the chaplain when he invaded her mistress's chamber of the morning of the visit," and William Eure was reported to have said that had Mr. Rhodes been present "he woold have gelded him." 93 Hoby's reading partners, in other words, were among the most controversial, and occasionally unpopular, men in Yorkshire religious politics.

While Hoby's reading practices were in many ways specific to the north, the worlds of Hoby's Yorkshire activism and the larger sphere of religious politics centered in London were not completely separate. In the course of her long visit to London from October 1600 to March 1601, during which she appeared in public with Mrs. Thornborough, Hoby also attended the sermons of Stephen Egerton, a Presbyterian preacher and activist who had been suspended for refusing to subscribe to Whitgift's articles, and was soon to be silenced again for petitioning the lower house for a reformed prayer book. Hoby was frequently seen at his sermons at St. Anne's in Blackfriars, a location known for Puritan sermonizing. Her visits to her mother-in-law, and fellow Puritan activist, Lady Elizabeth Cooke Hoby Russell, often involved an Egerton sermon (on October 19, for example, Hoby "went to Mr Egertons sermon, and after Came to my lady Russils to Diner" [150], and on the 26th she "went by water to the blake friers and hard Mr Egerton : after, I saw my lady Russill” [151]; see also October 16 and 17, November 30). 94 In contrast to the wonders of Egerton, her visit to Westminster is

92. Ordained in 1597, Rhodes served as chaplain to the Hobys from 1599 to 1605 , and from 1605 to 1614 he served as perpetual curate (a minister in charge of a parish that lacks either a rectory or vicarage) of Hackness. On Rhodes's career and his chastisement by the courts for his unconventional ministry, see Marchant, The Puritans and the Church Courts, 26, 37-38, 48. For example, Rhodes was cited in the Chancery Court, 29 July 1631 for holding conventicles in his own house during 1625-30 inclusive. Rhodes admitted that scholars of the Grammar School met at his house on Sundays to repeat the day's sermon (they wrote it on "tablets" and he revised its main points) and that he had catechized servants in his house in the evening.

93. Heal, "Reputation and Honour," 172.

94. She revisited his sermons on November 29, 1601, after returning to Yorkshire: "This day I went to the church and hard both the Lecturs: and at Night went to privatt praier, after Mr Hoby had reed unto me some notes of Mr Egertons Lecturs" (193). On Egerton, see Moody, Private Life of an Elizabethan Lady, 207-9, and the ODNB. 
disappointing: "I went to the minster and hard one Mr Smith preach, wher I hard, to my knowledge, nothinge worth the notinge" (151).

Hoby's later visits to London after the accession of James I (April-June 1603 and November 1604-February 1605) also seem to have been forms of Puritan activism. 95 Indeed, her commitment to Egerton both increased and became more public. She went to hear Egerton in London less than a month after James became king, and in the midst of the millenary petition scandal (April 12, 1603; 202). She heard him again on November 21, 1604 ("I waited on my Lady Russill to Mr Egerton's Lecture" [214]), and again on the following Sunday. After attending this sermon, Hoby records that "Mistress Cartwright came to se my Lady [Russell]" (214). This meeting of two powerful Puritan women is interesting in its own right-"Mistress Cartwright" was Thomas Cartwright's widow, the equally radical Alice Cartwright, and Elizabeth Russell was famed not only for her learning, but also for her support of Presbyterianism and Puritan preachers. ${ }^{96}$ But I am most interested in Hoby's note that she "delivered Sir Arthure Dakins message" to Mrs. Cartwright (214).97 Sir Arthur Dakins was Margaret Hoby's first cousin and a powerful figure in northern politics; the fact that she serves as his emissary-indeed, as his secretary—suggests both the extent and the nature of her participation in Yorkshire Puritan activism. Hoby had frequent interactions with Dakins in Yorkshire, many of which involved textual exchange. On one occasion Hoby writes: "I reed abroad wth my Cosine Dakine: after I Came home and that I had dined, I talked of good matters wth him, and he reed to me" (June 22, 1601; 176-77). The fact that they "reed" both "abroad" and at "home" further undermines the false distinction between men's public and women's private reading in the period. The play on "reed," meaning both "ride" and "read," serves to highlight the relationship between movement and reading that characterizes their activity. Margaret Hoby and Arthur Dakins's "reed[ing]" practices both publicly advertised their families' commitments and endeavored to bring the community into conversation, if not consensus, with their own beliefs. ${ }^{8}$ When Hoby gives Cartwright Dakins's message, moreover, we see trafficking

95. For a contrasting reading to my own, see Pauline Croft's argument about the Hobys' visits to London ("Capital Life," 69-73), which largely dismisses Margaret's politicking, focusing instead on Sir Thomas's. While her husband was engaged with a powerful "circle of men," writes Croft, his wife "bought two spinning wheels ... to keep herself occupied" (70). Although she notes that "Sermon going by members of parliament and their wives assisted the transmission of godliness to the localities" (73), Croft's presumptions about the labours of "wives" limits both her reading of the diary and her understanding of the workings of power and influence.

96. On Elizabeth's pursuit of Margaret and disappointment in her son, see Elizabeth Farber,

The Letters of Lady Elizabeth Russell (1540-1609) (PhD diss., Columbia University, 1977), 111-14.

97. Alice Stubbs Cartwright was sister to John Stubbs, author of The Gaping Gulfe (see ODNB for Thomas Cartwright). In November 1603, Thomas Cartwright was involved in the renewed campaign for further reformation upon the accession of James. He was meant to be at Hampton Court in January 1604, but died in December 1603.

98. Her interactions with Arthur Dakins were particularly bookish. In addition to having him read to her, at one point she records "readinge of a book [Arthur Dakins] sent me" on June 20, 1602 (198). 
between the Puritan gentry of the north and the "underground" Presbyterian-Puritan forces that were working for further reformation in the first year of James's reign. 99

In April 1603, right after the death of Elizabeth and the accession of James, and six months before she passed Arthur Dakins's message to Alice Cartwright, Hoby reports that "Lady Russill," "required the names of such as I would trust to passe some Livinge, after hirr death, unto me" (203). ${ }^{100}$ Russell, herself famous for arranging for the parish appointments, or livings, of Puritan preachers, evidently felt that Margaret Hoby-not her own son-should carry on her history of recommending Puritan ministers for specific benefices. ${ }^{101}$ Indeed, there is some evidence that Hoby did just that: John Philips, a minister whom the Hoby/Dakins clan heard at Thorpbassitt and then hosted at Winteringham (Margaret Hoby's mother's parish) in 1603 (205), was later nominated by Sir Thomas for a much more influential living at Middlesbrough. ${ }^{102}$ More significantly, it was only after this exchange about livings that Rhodes obtained his official benefice as rector of Hackness, the Hoby seat. While it is impossible to retrace the specific means by which these men obtained their livings, Margaret Hoby's religio-political exchanges seem to have played a role not only in the ministerial face of Yorkshire, but in the region's relations with the London Presbyterian movement that gained new energy, at least temporarily, with the accession of James I.

The Hobys, like many Puritans, looked forward to the accession of James with both trepidation and hope. ${ }^{103}$ Their hopes for further reform were misplaced. On November 17, 1603, Hoby records that "Mr Netelton brought us the Kinges proclimation for the restrainine some Combustious persones that sought reformation" (208). This proclamation was followed by the deprivation of multiple ministers (on January 8 , 1604, Hoby records: "This day was Mr Egerton, wt diuers others, silenced by the Bisshoppe of London" [215]), and the Hampton Court Conference in January 1604, which sought to further silence the renewed activism of Presbyterian-minded Puritans.

99. Not only did Cartwright's views remain alive to Hoby—she read or had others read Cartwright to her on a number of occasions (see, for example, 99)-but much of her reading was in fact the work of the old Presbyterian vanguard, believed to have been driven fully underground by the period in which Hoby was writing. She was also visited by Job Throckmorton, another influential Puritan controversialist (see Moody, Private Life of an Elizabethan Lady, 127 n. 224, and Meads, Diary, 274-75 n. 409).

10o. This note is syntactically cryptic; both of Hoby's editors see it as a sign of Russell reflecting on her own mortality; the term "Living," however, suggests that the women are talking about church livings, and thus of the appointments of the right kind of preachers to these livings or benefices.

101. For a discussion of the Cooke sisters, Hoby, and women's intellectual circles, see Julie Crawford, "Literary Circles and Coteries," The History of British Women's Writing, 1500-1610, ed. Caroline Bicks and Jennifer Summit (Basingstoke, U.K.: forthcoming 2010).

102. On John Philips, rector of Thorpe Basset, Margaret's mother's seat, from 1582 to 1605 , see Marchant, The Puritans and the Church Courts, 27, 269.

103. On the Hoby household's anxiety about the accession of James, see March 27, 1603: "went Mr Hoby and myselfe towards Yorke, thinkinge to Continewe there until all thinges were established: but he received letters from the Counsill att Yorke" (202). On April 4 "Came Letteres from the Kinge that everie Counsiller and other offecer should Continew in their places until his further pleasur were knowne" (202). 
While the archbishop of York, Mathew Hutton (whom Peter Lake has called a "puritan bishop"), saw the Catholics rather than the Puritans as the real threat to regional security, James vehemently disagreed. ${ }^{104}$ In February 1604, the king wrote to Hutton ordering him to bring Yorkshire Puritans to conformity. The Puritans' focus on papists, he argues, diverted "our looke from them selves, while they were plotting and contriveing all thinges that could be imagined likelie to deprive that state of the Church as it is established in our kingdome, and to bring in a forme of presbyterie, to the utter dissolucion of all monarchies." Hutton must suppress and bring to conformity all those "malitious contentions againste the Bishops and ecclesiasticall policy here by lawe established," and deprive any ministers "not conforming to the Booke of Common Prayer and ceremonies of the Church." 105 Less than two months after this letter, on Sunday, April 14, 1605, Hoby makes the following entry in her diary: "This day was the first day that the Commune praier Booke was read in our Church" (217). While Meads suggests this was because 1605 was the first year in which Richard Rhodes signs the register as parish priest, and a sign that "the former priest was unsatisfactory" (289 n. 612), I see it as a sign of the exact opposite: Hoby was recording her church's capitulation to the newly strict enforcement of anti-Puritan ecclesiastical policy under James. The "Commune praier Booke," a text specifically designed to foster Church of England conformity in the diverse parishes of England, was the antithesis of the varied practices of reading and disputation Margaret Hoby so actively pursued. The fact that these practices were aimed, in substantive if subtly executed ways, at encouraging Presbyterian thinking, suggests that, at least to some extent, James was right: whether or not they were committed to the dissolution of the monarchy, people like Hoby did want "to bring in some form of presbyterie" in England. Reading, moreover, was one of their key strategies.

\section{宓}

As a record of her reading in the company of others, including those reviled by James as "obstinant and obdurate ministers," 106 Margaret Hoby's diary is testament to her public and goal-oriented reading practices. As we have seen, she reads, with a wide range of co-readers, texts ranging from Acts and Monuments to the work of the authors most associated with the heyday of Elizabethan Presbyterian activism and its reactivation with the new century (and new monarch). She also hears and discusses the texts of

104. For Hutton's defense of all but the most radical Puritans, see Peter Lake, "Matthew HuttonA Puritan Bishop?" History 64, no. 211 (1979): 182-204. Hutton circulated manuscripts in the north and at court, including a position paper on predestination meant to encourage the Calvinist heads in the 159os, and a letter supporting Puritans after the Hampton Court conference, which he allowed to be circulated in the north (199). See also Hutton, Correspondence, 25.

105. In this letter, dated February 19, 1604, James further asked Hutton to put a stop to gossip that he planned greater religious toleration and expressed his anger at those who continued to support Nonconformist ministers and challenge established church policy; Hutton, Correspondence, 171-75. 106. Ibid., 174 . 
a still larger group of active Puritan authors, from the sermons of Stephen Egerton in Blackfriars, to those of the often unbeneficed, controversial, and policed ministers working, often in an activist capacity, in the largely recusant Yorkshire countryside. The motivated nature of her reading thus encourages us to reflect on her writing of her diary-and indeed on the genre of the diary itself.

As Elizabeth Clarke has shown, early modern women's spiritual journalsusually seen today as private documents-were often used for public, political purposes. Written and circulated either as hagiography or in support of a Presbyterian or Nonconformist movement, many of these scribal texts were even meant to be read aloud in other congregations. ${ }^{107}$ While I am not suggesting that Hoby's diary was meant to be read in this way-we have no evidence one way or another-Hoby's simultaneous avowal of Puritan opinions and politic circumspection about such matters as the Book of Common Prayer, and the nature of her household's often conventiclelike religious practices, suggests that she understood her diary, like her reading, as something of a public act - the record less of a private individual than of a collective social, religious, and political struggle. Just as Hoby's reading of de Mornay provides evidence that women read for action, so does her diary suggest that recording one's reading was a way of registering and affirming religious and political alliances. The fact that this aspect of Hoby's diary has been largely obscured may be a result of her own caution, but it is also the result of critical preconceptions about the genre of the diary and the nature of women's reading-ones, I hope, that this essay has done some work to unsettle.

The author wishes to thank the librarians at York Minster Library, especially Deirdre Mortimer and Peter Young; Susan Green and Heidi Brayman Hackel; and Pam Brown, Natasha Korda, Bianca Calabresi, Bella Mirabella, Mary Bly, Tanya Pollard, and, in memoriam, Sasha Roberts.

- JULIE CRAWFORD is an associate professor of English and Comparative Literature at Columbia University and the author of Marvelous Protestantism (2005). She has written essays on Shakespeare, Margaret Cavendish, John Fletcher, the Sidneys, Anne Clifford, and Mary Wroth, as well as on many aspects of postReformation religious and literary culture. She is currently completing a project about women and the production of coterie literature in early modern England.

107. Elizabeth Clarke, "Beyond Microhistory: The Use of Women's Manuscripts in a Widening Political Arena," in Women and Politics in Early Modern England, 1450-170o, ed. James Daybell (Aldershot, U.K., 2004), 211-27 at 217. See also Elizabeth Clarke, "Elizabeth Jekyll's Spiritual Diary: Private Manuscript or Political Document?” English Manuscript Studies, 110o-170o, vol. 9. Writings by Early Modern Women, ed. Peter Beal and Margaret J. Ezell (London, 2000), 218-37. 
This content downloaded from 128.59.160.148 on Tue, 7 Apr 2015 12:56:14 PM All use subject to JSTOR Terms and Conditions 